Ks. Jan Miazek

\title{
STRUKTURA NABOŻEŃSTW EUCHARYSTYCZNYCH W PRAKTYCE PARAFIALNEJ
}

\section{NABOŻEŃSTWA EUCHARYSTYCZNE W KOŚCIELE}

Nabożeństwa eucharystyczne należy widzieć na tle wszystkich nabożeństw istniejących w Kościele i dotąd odprawianych we wspólnotach wierzących. Sobór Watykański II dokonuje wielkiej reformy liturgii stwierdził, że ,zaleca się usilnie nabożeństwa ludu chrześcijańskiego, zgodne z przepisami i zasadami Kościoła", tak nabożeństwa znane w całym Kościele jak i nabożeństwa Kościołów partykularnych. Zalecił też tak uporządkować nabożeństwa, aby ,zgadzały się z liturgią, z niej poniekąd wypływały i do niej wiernych prowadziły" (por. KL 13). Słowa Soboru odnosiły się także do nabożeństw eucharystycznych. Praktyka wykazała, że w dobie odnowy liturgii położono wielki nacisk na samą liturgię, co spowodowało ograniczenie lub zanik wielu nabożeństw. W dużym stopniu przyczyniły się do tego także współczesne warunki życia: wierni posiadają więcej wolnego czasu, ale mają też wiele interesujących propozycji umożliwiających przyjemne spędzenie go. Wszystko to sprawiło, że mniej jest obecnie w Kościele nabożeństw eucharystycznych i mniej wiernych bierze w nich udzial.

Kościół świadom powstałej sytuacji przypominał o podtrzymywaniu pobożności eucharystycznej oraz mówił o potrzebie nabożeństw tak prywatnego jak i publicznego względem Sakramentu Ołtarza. W instrukcji Eucharisticum Mysterium z 1967 roku znajdujemy punkt o „pobożnych i świętych nabożeństwach eucharystycznych”. Są one nadal zalecane, a ich uporządkowanie powinno zostać dokonane zgodnie z duchem decyzji Soboru. W 1973 roku ukazały się obrzędy zebrane pod tytułem Komunia święta $i$ kult Tajemnicy Eucharystycznej poza Msza święta. W rozdziale „Różne formy kultu Najświętszej Eucharystii” czytamy, że „chociaż ofiara eucharystyczna jest źródłem i szczytem całego życia chrześcijańskiego, należy usilnie rozwijać również poza Mszą św. prywatne i publiczne nabożeństwa do Najświętszej Eucharystii według zasad ustalonych przez prawowitą władzę" (por. n. 55). Podobnie czytamy w instrukcji Inaestimabile donum z 1980 roku: „Zaleca się gorąco nabożeństwo zarówno publiczne jak i prywatne do Najświętszego Sakramentu także poza Mszą św." (por. n. 20). W tym samym roku o uwielbieniu Chrystusa w Najświętszym Sakramencie pisał też Ojciec św. Jan Paweł II w liście wielkoczwartkowym skierowanym do wszystkich biskupów Kościoła, a traktującym o tajemnicy i kulcie Eucharystii. Wspomina Ojciec św. o różnych formach pobożności eucharystycznej i dalej dodaje „Ożywienie i pogłębienie kultu eucharystycznego jest sprawdzianem praw- 
dziwej odnowy, tej, którą Sobór postawił sobie za cel. Jest tej odnowy punktem poniekąd kulminacyjnym. Kościól i świat odczuwają wielką potrzebę kultu eucharystycznego" (por. n. 3). Nowy Kodeks Prawa Kanonicznego stanowi, że w kościołach lub kaplicach, które mają zezwolenie na przechowywanie Najświętszej Eucharystii, można dokonywać jej wystawienia (kan. 941, 1). Nadto zaleca się, aby w tych kościołach i kaplicach organizowano corocznie uroczyste wystawienie Najświętszego Sakramentu przez odpowiedni czas (kan. 942).

Przypominamy pokrótce wypowiedzi Kościola na temat nabożeństw eucharystycznych bowiem nawet w naszym Kościele polskim można obserwować ich ograniczenie, zwłaszcza w dużych miastach. Powszechnie odprawiana niegdyś Godzina święta została sprowadzona do krótkiej adoracji po Mszy św. wieczornej. Przed nami staje również zadanie ożywienia kultu eucharystycznego. Jest to tym bardziej konieczne, że nabożeństwo eucharystyczne gromadzi na modlitwie Kościół, staje się ono miejscem wspólnej modlitwy wierzących w Chrystusa. Zmniejszenie ilości nabożeństw eucharystycznych oznacza mniej wspólnotowej modlitwy Kościoła, bowiem na ich miejsce nie przychodzą inne formy modlitwy wspólnej. W naszych kościołach nie jest wprowadzana na większą skalę wspólna Liturgia Godzin. Nabożeństw eucharystyczne mają swoją długą tradycję i nadal gromadzą dużą ilość wiernych.

\section{DOTYCHCZASOWA STRUKTURA NABOŻEŃSTW EUCHARYSTYCZNYCH}

Struktura nabożeństw eucharystycznych ukształtowała się w przeszłości i w swej zasadniczej linii przetrwała do dziś. Pod wpływem reformy liturgicznej dokonano w niej pewnych zmian przez wprowadzenie czytań wziętych z Pisma św. Poszczególne diecezje posiadają swoje własne schematy, które w zasadzie nie różnią się tak wiele.

Służba Boża $w$ Archidiecezji Warszawskiej - księga opracowana w 1975 roku i dotąd używana w archidiecezji - zawiera kilka form nabożeństw eucharystycznych. Zatrzymajmy na nich naszą uwagę.

Adoracja wieczorna $\mathrm{w}$ dni powszednie jest przewidziana dla kościołów, w których nie ma Mszy św. wieczornej. Rozpoczyna się od wystawienia Najświętszego Sakramentu, po czym celebrans odmawia serię modlitw przeplatanych śpiewem pieśni. Schemat modlitw jest następujący: modlitwa uwielbienia, modlitwa dziękczynienia, akt pokuty i prośby. We wszystkich tych modlitwach uczestniczy lud przez powtarzanie odpowiedniego refrenu. Teksty podanych modlitw nie są obowiązujące: celebrans może je układać samodzielnie lub korzystać $\mathrm{z}$ odpowiednich publikacji. Przed zakończeniem adoracji zalecona jest modlitwa w ciszy, do której celebrans może wprowadzić krótkim rozważaniem słów Chrystusa, wybranych np. z ewangelii dnia. Adorację kończy błogosławienstwo eucharystyczne. 
Adoracja miesięczna $\mathrm{w}$ niedzielę, dowolnie wybraną na stałe, jest obowiązkowa w kościołach parafialnych. Wskazane jest, aby miała miejsce po Mszy św., ale można ją też odprawić niezależnie od Mszy św. Księga podaje dwa sposoby odprawiania adoracji. Sposób pierwszy: wprowadzenie celebransa, wystawienie Najświętszego Sakramentu, cisza na modlitwę indywidualną, czytanie fragmentu ewangelii opisującego ustanowienie Najświętszego Sakramentu. Teraz następuje wyznanie wiary $w$ tajemnice Eucharystii. Po śpiewie i ciszy na indywidualną modlitwę, przychodzi modlitwa o jedność i miłość wzajemną. Po jeszcze jednym śpiewie i ponownej modlitwie w ciszy, celebrans odmawia modlitwę końcową. Drugi sposób odprawienia adoracji, przejęty z dawnego Porządku nabożeństw (1962) zawiera modlitwy przeplatane śpiewem. Modlitwy te to akt wiary, akt uwielbienia, akt dziękczynienia, akt przebłagania i akt prośby. Spojrzenie na obydwa sposoby adoracji uwypukla różnice: w pierwszym, powstalym już po reformie soborowej, dodano czytanie ewangelii i wprowadzono momenty ciszy. Adoracja miesięczna może być połączona z procesją eucharystyczną, a zawsze kończy ją błogosławieństwo eucharystyczne.

Godzina święta jest nabożeństwem odprawianym w czwartki przed pierwszym piątkiem miesiąca. Jej schemat jest prosty: wystawienie, adoracja i błogosławieństwo. Księga nie zawiera przykladów ad racji, ale zaleca korzystanie ze wzorów zawartych w „Biblistece Kazno(lziejskiej" lub w innych podobnych publikacjach.

Doroczna adoracja, zwana dawniej czterdziestogodzinnym nabożeństwem, ma miejsce we wszystkich kościołach i kaplicach publicznych. W pierwszym dniu Doroczną Adorację rozpoczyna Msza św., po której następuje wystawienie Najświętszego Sakramentu, krótka adoracja i procesja. Po powrocie do oltarza odmawiana jest litania do Imienia Jezus, a następnie rozpoczyna się adoracja prywatna. W porze, w której zebrać się może w kościele większa liczba wiernych, wypada odprawić wspólną adorację. Wieczorem kończy się wystawienie Najświętszego Sakramentu nieszporami o Najświętszym Sakramencie lub Mszą św. Drugi i trzeci dzień adoracji przebiega podobnie. Dproczną Adorację kończy procesja. Księga podaje schemat wspólnej adoracji złożonej $\mathrm{z}$ trzech części. Czytany jest fragment ewangelii o tajemnicy eucharystii (I i III cz.) lub fragment dekretu $O$ posiudze i życiu kapłanów (II cz.). Przeczytane teksty zgromadzeni medytują w modlitewnej ciszy, po czym celebrans prowadzi modlitwę wspólną. Adoracji towarzyszą śpiewy.

Agenda liturgiczna diecezji opolskiej, wydana w 1981 roku, jest najnowszą księgą diecezjalną o takim charakterze i rozeszła się po całej Polsce niesłychanie szybko. Nabożeństwa eucharystyczne zawarte w Agendzie nawiazuja do tradycji regionu.

Czterdziestogodzinne nabożeństwo - zwykle całodzienna adoracja Najświętszego Sakramentu w niedzielę, poniedziałek i wtorek przed 
Środą Popielcową. Podczas tego nabożeństwa należy urządzić godziny adoracyjne, jedną z propozycji zawiera Agenda. Znajdujemy przy tym uwagę, że podczas godzin adoracyjnych zaleca się czytanie słowa Bożego $z$ VII tomu lekcjonarza.

Nieustanna adoracja - odprawiana jest w stałych terminach w poszczególnych kościołach. Jest to adoracja całodzienna lub nocna. $\mathrm{Na}$ poszczególne godziny adoracyjne zaprasza się różne grupy parafian, zaś wzór nabożeństwa można czerpać z Agendy.

Godzina święta - w czwartki przed pierwszym piątkiem miesiąca, może być odprawiana przed lub po Mszy wieczornej. Agenda podaje wzór takiej adoracji: modlitwa wstępna, czytanie Pisma św., cisza modlitewna lub krótka homilia. Następnie ma miejsce rozważanie tajemnicy Eucharystii: rozważanie wychodzi od tekstu Pisma św., towarzyszy mu śpiew. Po obu rozważaniach znajdują się modlitwy błagalne bardzo rozbudowane. Całość kończy błogosławieństwo.

Patrząc na dwie księgi dwóch diecezji w Polsce widzimy, jak nabożeństwa eucharystyczne różnie mogą być w diecezjach odprawiane. Można powiedzieć, że każda diecezja posiada własną tradycję w organizowaniu kultu Eucharystii poza Mszą św.

„Biblioteka Kaznodziejska” przynosi na każdy miesiąc tekst adoracji podczas Godziny świętej. Ponieważ kapłani wykorzystują przygot Jwany materiał zatrzymamy teraz uwage na kilku wzorach adora ji. Godzina święta na sierpień 1982 roku nosi tytuł „Witaj święta Wędrowniczko", nawiązuje bowiem do odbywanych w tym czasie pielgrzymek. Po śpiewie wstępnym znajdujemy modlitwę dziękczynienia Ojcu za Maryję. Po modlitwie w ciszy przychodzą wezwania do Jezusa umierającego na krzyżu o charakterze pochwalnym. Następnie celebrans czyta fragment Ślubów Jasnogórskich, po czym odmawia wezwania do Maryi zakończone osobistą refleksją nad przeżyciem ostatniego nawiedzenia obrazu w parafii. Znów powracają wezwania pochwalne skierowane do Chrystusa oraz wezwania skierowane do Maryi przyzywające Jej wstawiennictwa. W omawianym tekście zwraca uwagę przemieszanie modlitw zwróconych do Chrystusa i do Maryi. Godzina święta na październik tego samego roku nosi tytuł „Matko codziennej modlitwy” i nawiązuje treścią do modlitwy różańcowej. Rozważanie osnute jest na tle tajemnic radosnych różańca, a zbudowane jest $w$ formie wezwań skierowanych do Ojca. Każdą serię wezwań kończy prośba do Maryi. Godzina święta na luty 1983 roku nosi tytuł „Jezusie, Synu Dawida, ulituj się nade mną". Jest oparta na schemacie mszalnej liturgii słowa. Po pieśni otwarcia umieszczona jest modlitwa, która przechodzi w ciszę. Następnie jest czytanie z Jeremiasza $(31,7-13)$ i wezwania do Ojca o wyzwolenie $\mathrm{z}$ niewoli. Po śpiewie i prośbie do Maryi czytany jest fragment Ewangelii św. Marka (10, 46-52), po czym mamy dwie serie wezwań do Jezusa, wezwań za siebie i za ludzi pozostających w różnych utrapieniach. 
Trzy przytoczone przykłady ukazują, ze struktura adoracji podczas Godziny świętej jest zmienna, zmienia się nawet, jeśli chodzi o tego samego autora. Jest to świadomie zamierzone i prawdopodobnie ma bronić uczestników modlitwy przed monotonią. Podawane wzory adoracji nawiązują też do okresów liturgicznych, do charakteru danego miesiąca czy też do obchodzonego akurat w tym miesiącu większego święta. W swej treści adoracje są zasadniczo chrystocentryczne, ale jest $w$ nich również wiele modlitwy skierowanej do Maryi.

\section{ODNOWIONA STRUKTURA NABOŻENSTW EUCHARYSTYCZNYCH}

Księga liturgiczna Komunia święta i kult Tajemnicy Eucharystycznej poza Msza św. przynosi najnowsze postanowienia odnośnie nabożeństw eucharystycznych. W rozdziale II zatytułowanym „Różne formy kultu Najświętszej Eucharystii" omawia takie oto nabożeństwa eucharystyczne: wystawienie trwające przez dłuższy okres czasu, wystawienie trwające przez krótki okres czasu, procesje, kongresy eucharystyczne. Trzy $z$ wymienionych form kultu praktykowane sa powszechnie w parafiach i dlatego przejdziemy do ich omówienia.

Wystawienie trwające przez dłuższy okres czasu powinno odbywać się uroczyście co roku w kościołach i kaplicach, w których na stałe przechowuje się Najświętszy Sakrament. Wystawienie to odpowiada naszemu czterdziestogodzinnemu nabożeństwu. Dokument rzymski i nasze polskie wydanie księgi nie używają tej tradycyjnej nazwy, bowiem ona nie odpowiada już obecnej praktyce. Wystawienie pozwala miejscowej wspólnocie na nowo rozważyć tajemnicę Eucharystii i okazać jej należną adorację. Wystawienie to może odbywać się jedynie wtedy, gdy przewiduje się udział odpowiedniej liczby wiernych. W razie ważnej i powszechnej potrzeby biskup może nakazać modlitwy blagalne przed wystawionym Najświętszym Sakramentem, ale w tych kościołach, do których wierni liczniej uczęszczają. Jeśli podczas wystawienia brak odpowiedniej liczby adorujących, można na pewien czas schować Najświętszy Sakrament.

Struktura wystawienia trwającego przez dłuższy czas nie została określona w dokumencie rzymskim i nie określa jej nasze polskie wydanie księgi Komunia święta i kult Tajemnicy Eucharystycznej poza Msza święta. Wskazuje to na istnienie różnych tradycji lokalnych, których nie chciano obalać przez wprowadzenie ujednoliconego rytu. Poszczególne parafie stosują się do zwyczajów diecezji. Należy przypuszczać, że zawsze podczas tego wystawienia mają miejsce godziny adoracyjne dla poszczególnych grup wiernych.

Wystawienie trwające przez krótki okres czasu - tą dosyć długą nazwą zachowaną również w polskim wydaniu rytuału określone są nasze zwykle nabożeństwa eucharystyczne. Rytuał podaje obrzęd wy- 
stawienia krótkiego: wystawienie Najświętszego Sakramentu w puszce lub monstrancji, adoracja i błogosławieństwo eucharystyczne. Jest to tradycyjny schemat, w którym najbardziej interesuje nas sama adoracja. Rytuał odnośnie adoracji podaje tylko bardzo ogólne wskazania pozostawiając tym samym dużą swobodę w jej układaniu. Oto jakie elementy powinny wystąpić w adoracji: czytanie Pisma św. połączone ewentualnie $\mathrm{z}$ homilią, modlitwy, śpiewy jako odpowiedź na slowo Boże, święte milczenie. Układ tych elementów nie jest określony, co pozwala na swobodę układu adoracji, którą w ten sposób można dostosować do poziomu duchowego uczestników i uchronić ją od schematycznej monotonii. Rytual rzymski pozostawia w tym swobodę poszczególnym Kościołom krajowym, zaś nasz rytuał polski poszczególnym diecezjom.

Procesje eucharystyczne według przepisów omawianego rytuału powinny zawsze wychodzić poza kościół. Miejscowy biskup osądza, czy można urządzać procesje, oraz określa czas, miejsce i porządek procesji. Najwięcej uwagi poświęcono procesji Bożego Ciała, inne zaś procesje powinny być na niej wzorowane. Nie ma zaś najmniejszej wzmianki o procesjach urządzanych wewnątrz kościołów, co ma również miejsce w kościołach rzymskich. Rytuał nie mówi wprost o niestosowności tej praktyki, w jakiś sposób chyba godzi się na dotychczasową praktykę. W Kościele polskim procesje wokół i wewnątrz kościoła są powszechnie urządzane, stały się bardzo popularną formą nabożeństwa eucharystycznego. Wydaje się, że utrata tych procesji byłaby zubożeniem kultu eucharystycznego. Biskup określa czas, miejsce i porządek procesji, czyni to również $w$ odniesieniu do procesji parafialnych. Struktura tych procesji jest prosta, wiele przy tym miejscowych zwyczajów i praktyk. Wydaje się, że do procesji nie wiele można dodać: chyba jedynie krótkie słowo wprowadzenia byłoby pomocą dla uczestników, słowo pogłębiające.

\section{STRUKTURA NABOŻEŃSTWA PODPORZĄDKOWANA TREŚCI}

Rytuał wyliczając elementy nabożeństwa eucharystycznego, a nie mówiąc o ich ukałdzie, zdaje się wskazywać na to, że ważniejsza jest treść nabożeństwa niż jego układ formalny.Jako zasadę ogólną przyjęto, że „podczas wystawienia należy modlitwy, śpiewy i czytania ułożyć tak, by wierni skupili swoją uwagę na Chrystusie Panu" (n. 71). Nabożeństwo adoracyjne ma więc posiadać wyraźnie chrystologiczny charakter.

Modlitwy, śpiewy i czytania powinny uczyć prawdziwej pobożności eucharystycznej i stąd mają zawierać następujące treści. Najpierw mają kierować wiernych do pełnego udziału w tajemnicy paschalnej Chrystusa i do wdzięczności za dar Chrystusa dającego nam swoje życie. Powinny wyrażać radość zebranych z życia w głębokiej przyjaźni ze Zbawicielem, prowadzić do otwarcia serca przed Nim. Wyra- 
żać potrzeby własne zebranych, ich bliskich, wszystkich ludzi i wołać tak o pokój jak i o zbawienie dla całego świata. Wspólna modlitwa zebranych ma wzbudzić: w nich pragnienie ofiarnego życia dla Chrystusa, pragnienie zjednoczenia $z$ Nim w Komunii św. Nadto udział w adoracji ma prowadzić do pełnienia dobrych czynów, do podjęcia mișji zbawczej wobec świata, do świadezenia o Chrystusie. Tak więc w ukladzie adoracji znajdą się modlitwy uwielbienia i chwaly; modlitwy rozważające tajemnicę Chrystusa, modlitwy błagalne i prośby nawet $\mathrm{w}$ bardzo konkretnych potrzebach. Trzeba przy tym dać zawsze pierwszeństwo uwielbieniu przed prośbą. Należy przy tym dokonywać roztropnego wyboru treści, bowiem nie możemy w jednym nabożeństwie wyrazić wszystkiego.

Nabożeństwa eucharystyczne mają być powiązane z poszczególnymi okresami liturgicznymi. Można to osiągnąć przez odpowiednie wprowadzenie, śpiewy z okresu liturgicznego lub przez dobrane modlitwy. Najbardziej pomocne stają się odpowiednio dobrane fragmenty Pisma św. lub perykopy właściwe danemu okresowi.

Czytanie Pisma św., w czasie nabożeństw eucharystycznych jest pewną nowością wynikająca z ducha reformy liturgii. Czytane fragmenty mają wprowadzic wiernych w głębsze rozumienie tajemnicy Eucharystii, ukazać jej poszczególne aspekty i związek tej tajemnicy wiary z duchowym życiem chrześcijanina. Odnośnie do sposobu wykorzystania Pisma św. należy trzymać się pewnych reguł. Fragmenty Pisma św., jeśli jest ich więcej, powinny układać się w pewną całość, zachowywać jedność myśli, odnosić się do jednego tematu, bowiem $\mathrm{w}$ przeciwnym razie dojdzie do wielowątkowości w nabożeństwie, trudnej do przyjęcia. Nie może też być zbyt wielu czytan, bowiem wtedy nabożeństwo eucharystyczne przez nadmiar słowa przekształci się w nabożeństwo słowa Bożego lub w godzinę biblijną. Nie wytworzy się wtedy klimat modlitewny tak nieodzowny przy adoracji. Wszystko to odnosi się również do homilii nawiązującej do tekstów biblijnych. Nabożeństwo eucharystyczne nie powinno stawać się miejscem intelektualnych rozważań czy pouczeń, ale powinno być czasem skupionej modlitwy. Nabożeństwo nie może zatracać charakteru modlitewnego. Stąd plynie postulat, aby teksty Pisma św. były czytane w odmienny sposób niż w zwykłej liturgii słowa, a głoszone słowo Boże winno bardziej przypominać rozważanie niż pouczenie. Jeśli zaś podczas nabożeństwa głoszone jest słowo Boże w formie pouczenia, powinno to zostać zrównoważone przez rozbudowany element modlitewny. Praktyka wykazuje, że lepiej jest wziąc mniej Pisma św. i wydobyć z niego ukryte treści, niż przytaczać zbyt wiele tekstów bez wchodzenia głębszego w ich treść. Wydaje się, że byłoby też rzeczą wskazaną umieszczenie czytań w pierwszej części nabożeństwa, drugą zaś wtedy można poświęcić całkowicie modlitwie.

Milczenie modlitewne podczas nabożeństwa eucharystycznego jest zalecane, bowiem milczenie zostało na nowo odkryte w liturgii i do 
liturgii wprowadzone. Powie rytuak: w pewnych momentach dobrze jest zachować święte milczenie. Różne mogą to być momenty po czytaniu Pisma św., po serii wezwań modlitewnych czy nawet podczas odmawianej modlitwy. Wiele zależy przy tym od roztropności celebransa. Wydaje się, że milczenie można zachować we wspólnotach przygotowanych już do samodzielnej modlitwy. Do milczenia należy też stopniowo wychowywać uczestników nabożeństw eucharystycznych.

Należy zwracać uwagę na to, by przy wystawieniach uwydatniał się związek istniejący między kultem Najświętszego Sakramentu ze Mszą św. Związek ten uwydatnia się najbardziej, jeśli nabożeństwo eucharystyczne następuje bezpośrednio po Mszy św. O ile jest to teologicznie poprawne, to jednak w praktyce prowadzi do odprawiania skróconych nabożeństw eucharystycznych, co dzieje się ze szkodą duchową wiernych. W tych nabożeństwach bierze udział najpobożniejsza grupa wiernych i wierni ci są gotowi ponieść trud dodatkowego przyjścia. Podobnie jest $\mathrm{z}$ nabożeństwami poprzedzającymi bezpośrednio wieczorną Mszę św., nabożeństwo zwykle odprawiane jest w pośpiechu i w napięciu.

\section{NABOŻEŃSTWA Z WYYTTAWIENIEM NAJŚWIĘTSZEGO SAKRAMENTU}

O ile nabożeństwa eucharystyczne same w sobie nie przedstawiają zasadniczych problemów, to jednak problemem są nabożeństwa $z$ wystawieniem Najświętszego Sakramentu. Tak rzymskie jak i polskie wydanie rytuału milezy zupełnie na ten temat, a przecież to właśnie nabożeństwa $\mathrm{z}$ wystawieniem Najświętszego Sakramentu są najczęściej odprawiane w naszych kościołach. Przez cały miesiąc maj - nabożeństwo majowe, w październiku - nabożeństwo różańcowe, w Wielkim Poście - Gorzkie Żale. Rozwijające się ruchy maryjne mają swoje własne nabożeństwa przed wystawionym Najświętszym Sakramentem. Jeśli dodamy do tego różne nowenny i tridua, to otrzymamy dopiero wtedy pełny obraz kultu eucharystycznego. W obecnej sytuacji normy liturgiczne zdają się nabożeństw $z$ wystawieniem Najświętszego Sakramentu nie dostrzegać, co w konsekwencji prowadzi do rozdźwięku między przepisami liturgicznymi a codzienną praktyką parafialną.

Referat nasz nie traktował tylko o strukturze nabożeństw eucharystycznych, ale dotykał wielu jeszcze innych problemów związanych z tymi nabożeństwami. Niektóre $z$ nich wymagają dalszej rzeczowej dyskusji i konkretnych rozwiązań. Czas przygotowania do Kongresu Eucharystycznego sprzyja rozważaniom o tajemnicy Eucharystii i stwarza wielką okazję do ożywienia wszelkich form kultu eucharystycznego. 